\title{
Extreme sea events during the last millennium in the northeast of Morocco
}

\author{
O. Raji ${ }^{1}$, L. Dezileau ${ }^{2}$, U. Von Grafenstein ${ }^{3}$, S. Niazi ${ }^{1}$, M. Snoussi ${ }^{1}$, and P. Martinez ${ }^{4}$ \\ ${ }^{1}$ Department of Earth Sciences, Université MohammedV-Agdal, Rabat, Morocco \\ ${ }^{2}$ Geosciences, CNRS, UMR 5243 Université Montpellier 2, Montpellier, France \\ ${ }^{3}$ Sciences du Climat et de l'Environnement, CNRS/CEA, Saclay, France \\ ${ }^{4}$ UMR 5805 EPOC, OASU, Université Bordeaux 1, Bordeaux, France \\ Correspondence to: O. Raji (otmaneraji@gmail.com) and L. Dezileau (dezileau@gm.univ-montp2.fr)
}

Received: 27 January 2014 - Published in Nat. Hazards Earth Syst. Sci. Discuss.: 15 March 2014

Revised: 7 August 2014 - Accepted: 13 November 2014 - Published: 3 February 2015

\begin{abstract}
The Moroccan Mediterranean coast is located in one of the area's most vulnerable to extreme weather events or tsunami hazards. The objective of this research is to reconstruct the historical extreme submersion-event record using sea-induced deposits preserved in coastal lagoon. The Nador lagoon is the largest Moroccan lagoon $\left(115 \mathrm{~km}^{2}\right)$. It is located along the western Mediterranean, which has a high cyclogenetic character and is exposed to tsunamis from the Alboran Sea. The sandy barrier which separates the lagoon from the Mediterranean Sea is marked by much overwash, which indicate how intensely it has been exposed to the adverse sea events through history. Using the UWITEC $^{\odot}$ gravity coring platform, an undisturbed MC 4.5 core ( $1.15 \mathrm{~m}$ long) was successfully sampled in the studied lagoon. To identify extreme sea events, a multi-proxy approach was applied combining sedimentological and geochemical data. Three paleoevents were identified; all of them are concentrated over the last 500 years, and the most recent event corresponds to the 1889 storm. For the others deposits, it is difficult to determine exactly their origin; however, the high frequency of storm events over the relevant period and the absence of historical tsunamis evidence is more in favor of the meteorological origin.
\end{abstract}

\section{Introduction}

The Mediterranean region has experienced numerous extreme coastal events, weather events (Lionello et al., 2006) as well as tsunamis events (Papadopoulos and Fokaefs, 2005), which caused casualties and economic damages. Preventing the adverse impacts of such events requires studying their past frequency and intensity in order to predict future trends and determine their recurrence interval. However, the meteorological and marine instrumental records are limited to only a few decades, especially in southern Mediterranean countries. Thus, geological data offer the best way to reconstruct the historical records of intense hurricanes and tsunami activity (Liu and Fearn, 1993). The most appropriate sites for such studies seem to be the coastal lagoons with sandy barriers, which provide a source of material for transport and deposition as an overwash layer (Woodruff et al., 2008; Yu et al., 2009; and Dezileau et al., 2011). The reconstruction of paleoevents is made by identifying the recurrence of overwash coarse grained deposits and associated contents (Liu and Fearn, 1993; Collins et al., 1999; Nott, 2004; Dezileau et al., 2005; Donnelly and Woodruff, 2007; Scipelly and Donnelly, 2007; Sabatier et al., 2008). However, recent studies, used different proxies to identify any events that were large enough to cause seawater flooding of the coastal lagoons such as X-ray fluorescence (XRF) ratios, clay mineral (Sabatier et al., 2012) and stable isotopes composition on organic matter $\left(\delta^{15} \mathrm{~N}, \delta^{13} \mathrm{C}, \mathrm{C} \%, \mathrm{~N} \%\right.$ and $\mathrm{C} / \mathrm{N}$ ) (Das et al., 2013). These geochemical proxies are generally a more sensitive indicator, particularly where sand laminae/transported shells are indistinguishable or absent (Das et al., 2013).

The objective of this research is to reconstruct Paleolithic extreme sea events (sea storms or tsunamis) using a multiproxy analysis based on sedimentological and geochemical data in the Nador lagoon. This area is located along the Mo- 


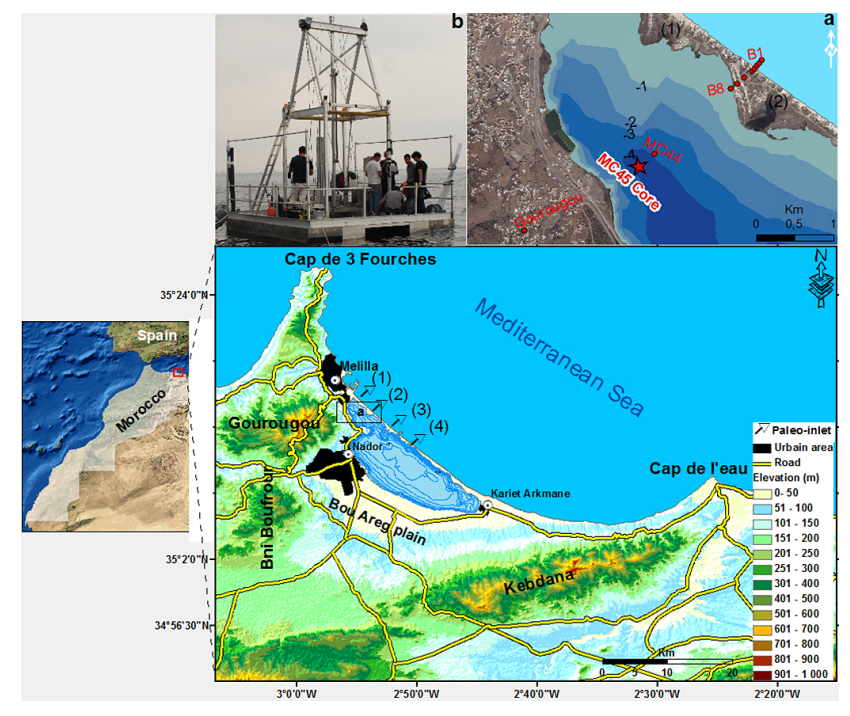

Figure 1. Map of the study area (the Nador lagoon): (a) the location of surface samples and the MC45 core sampled in the northwest of the Nador Lagoon. (b) UWITEC coring platform used in Nador campaign.

roccan Mediterranean coast, which is a part of the western Mediterranean sea that has a high cyclogenetic character ( $\mathrm{Li}$ onello et al., 2006; Campins et al., 2006). It is also prone to risks related to tsunami events; Gonzalez et al. (2010) have studied potential tsunamigenic sources in the Alboran Sea and identified Nador area as one of the most exposed to a large tsunami wave elevation. The Nador lagoon thus offers a real potential for reconstitution of sea paleoevents and this study is pioneer in the area.

\section{Study area}

The Nador lagoon, also called Sabkha Bou Areg or Mar Chica, is the only one located along the Moroccan Mediterranean coast between Melilla and the district of KariatArkmane (Fig. 1). The lagoon is surrounded by a dense urbanization which houses a large population of approx. 450000 inhabitants (RGPH, 2004).

The watershed, which drains an area of $700 \mathrm{~km}^{2}$, is formed by the following four morphological structures. (i) The first is northwest of the volcanic massif of Gourougou and is composed of Messinian to Plio-Quaternary calc-alkaline rocks (Morel, 1985). (ii) The second is in the west: the massif of Beni Bou Iffrour, which consists of limestones, Jurassic calcareous sandstones and marls, and of Cretaceous sandy shales and volcano-sedimentary series covered by the Miocene. (iii) The third is in the south: the Jurassic to MioPliocene Kebdana massif (Mahjoubi, 2001). (iv) The fourth is the Bou Areg plain in the southwest, which is of Neogenic to Plio-Quaternary age, characterized by salt marshes, and several intermittent streams with irregular flow (some of which presently serve as sewage outflows for urban areas) (Irzi, 2002). Dominant climatic conditions prevailing in the study area are that of typical Mediterranean climate, with hot and dry summers that contrast to mild and rainy winters. The strongest winds and waves are from the northeast and east. Mean significant wave height is less than $1 \mathrm{~m}$, although during storm condition it can reach $4.5 \mathrm{~m}$ (WANA Puertos del Estado wave data network).

The Nador lagoon is the largest Moroccan lagoon, with a surface area of approximately $115 \mathrm{~km}^{2}$; the average depth is $4.8 \mathrm{~m}$, and it has a maximum depth of $8 \mathrm{~m}$. Its genesis and evolution is mainly controlled by tectonics and climate (Hamoumi, 2012). It is isolated from the Mediterranean Sea by a $25 \mathrm{~km}$ long sandy barrier crossed by an artificial inlet recently opened and stabilized (2011). The northwest area of this lido is marked by much overwash, which indicates how intensely it has been exposed to the adverse sea events through history; because of that, an undisturbed core (MC4.5) was successfully sampled using the UWITEC coring platform in this area (Long: $35^{\circ} 14^{\prime} 3.30^{\prime \prime} \mathrm{N}$, Lat $2^{\circ} 55^{\prime} 17.50^{\prime \prime} \mathrm{W}$, Depth: $4.24 \mathrm{~m}$ ); superficial sediments were also collected during the coring campaign (Fig. 1).

\section{Methods}

The MC4.5 core was first split, photographed and logged in detail. Then, a multi-proxy approach was adopted by the combination of sedimentological, geochemical and geochronological data.

The sediment core was analyzed by X-ray fluorescence (XRF) using an XRF core scanner. With a step size of $0.5 \mathrm{~mm}$, a semi-quantitative analysis was performed directly on the surface of sediment; this surface had to be covered with a $4 \mathrm{~mm}$ thin Ultralene film to avoid contamination of the XRF measurement unit and desiccation of the sediment.

The analysis of particle size was performed on samples taken directly from the sediment core every $\mathrm{cm}$. Using a Beckman Coulter $^{\odot}$ LS 13 320, each sample was sieved at $1 \mathrm{~mm}$, suspended in deionized water and gently shaken to achieve disaggregation. After introduction of sediment into the fluid module of the granulometer, ultrasounds were used to avoid particles flocculation.

The ${ }^{137} \mathrm{Cs}$ and ${ }^{210} \mathrm{~Pb}_{\text {ex }}$ activities analyses were measured with a fine-grained fraction of less than $150 \mu \mathrm{m}$ ) by gamma spectrometry using a CANBERRA Broad Energy Ge (BEGe) detector (CANBERRA BEGe 3825). The ${ }^{210} \mathrm{~Pb}_{\mathrm{ex}}$ dating is based on the determination of the ${ }^{210} \mathrm{~Pb}$ excess activities in the layers of the core. The use of this natural radionuclide ${ }^{210} \mathrm{~Pb}_{\text {ex }}$ to determine sedimentation rate is now a well established technique (Goldberg, 1963; Krishnaswamy et al., 1971; Robbins and Edgington, 1975). The dating of ${ }^{137} \mathrm{Cs}$ was conducted according to Robbins and Edgington (1975). For the long-scale time, the radiocarbon $\left({ }^{14} \mathrm{C}\right)$ chronology was adopted using shell samples. 


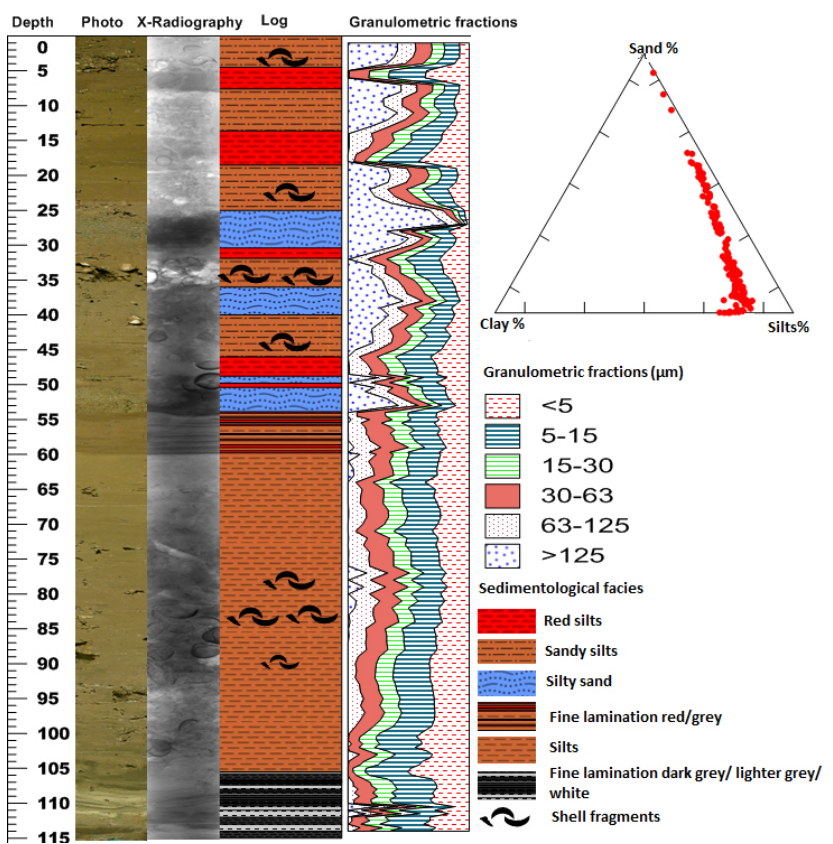

Figure 2. Photography, digital X-ray radiography, stratigraphic log and grain size results of MC45 core.

${ }^{14} \mathrm{C}$ analyses were conducted at the LMC14 laboratory on the ARTEMIS accelerator mass spectrometry at the CEA institute in Saclay (Atomic Energy Commission). These ${ }^{14} \mathrm{C}$ analyses were done with the standard procedure described by Tisnérat-Laborde (Tisnérat-Laborde et al., 2006).

\section{Results and discussion}

\subsection{MC45 Core description}

\subsubsection{Lithostratigraphy}

The MC45 sediment core of $115 \mathrm{~cm}$ long shows visual variations in sediment composition. Based on photography, digital X-ray radiography, and stratigraphic log and grain size results (Fig. 2), the core was roughly divided into four units. The passage from one unit to another is defined by a contact which is more gradual between levels 1 and 2 than it is between levels $2-3$ and $3-4$, where it is very steep:

- Unit $1(115-105 \mathrm{~cm})$ composed by silty fine laminae, three colors are observed; dark grey layers and lighter grey layers correspond to fine-grained sediments, while white layers associated with gypsum microcrystals correspond to relatively coarse sediments.

- Unit $2(105-60 \mathrm{~cm})$ is characterized by fine grained sediment and brownish gray color; it consists mainly of homogeneous silts with large number of shell fragments mainly at $75-100 \mathrm{~cm}$ interval.

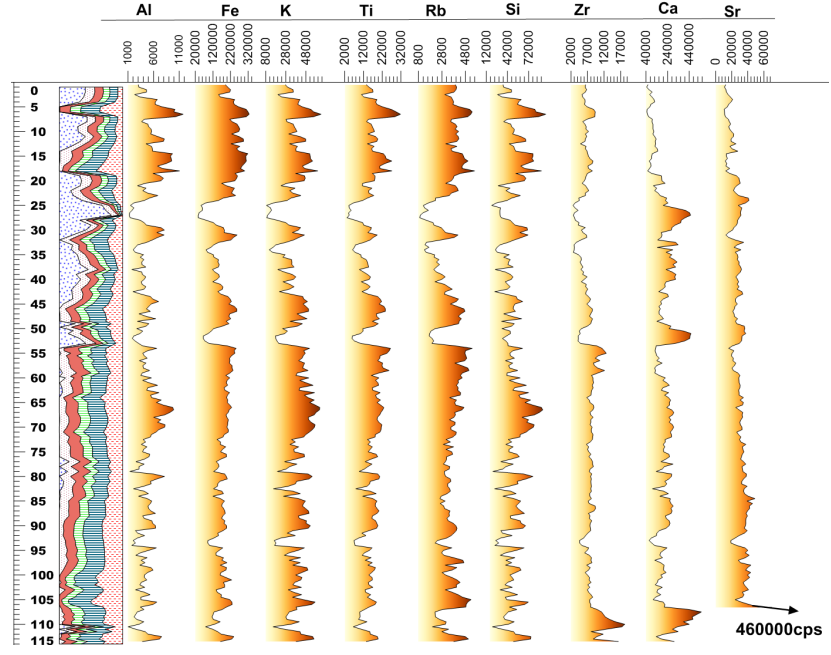

Figure 3. Down-core plots of signal intensity (cps, counts per second) vs. depth in MC45 of nine geochemical elements.

- Unit $3(60-54 \mathrm{~cm})$ composed by fine parallel-laminated silts, red layers relatively fine-grained and grey layers. These laminae are well observed in digital X-ray radiography (as intercalation of dark and light laminae).

- Unit $4(54-0 \mathrm{~cm})$ display several lithological changes. Three main faces can be identified: (i) silty sand characterized by coarse sediment with grey color (which appears very dark in radiographic images); (ii) sandy silts show brownish gray color and relatively coarse sediment, and are dominated by shell fragments; (iii) red silts consist of fine grained sediment with a relative absence of shell fragments.

\subsubsection{Geochemistry}

25 elements (Al, Si, P, S, Cl, K, Ca, Ti, V, Cr, Mn, Fe, Ni, Cu, $\mathrm{Zn}, \mathrm{Ga}, \mathrm{As}, \mathrm{Br}, \mathrm{Rb}, \mathrm{Sr}, \mathrm{Y}, \mathrm{Zr}, \mathrm{La}, \mathrm{Ta}, \mathrm{Bi}$ ) were detected in the Nador MC45 core sediment; however most of them exhibit noisy profiles. Therefore, only elements which present the most important variations through depth were selected and down-core plots of signal intensity (cps, counts per second) vs. depth are presented in Fig. 3. Based on their profiles, the group composed by $\mathrm{Al}, \mathrm{Fe}, \mathrm{Ti}, \mathrm{K}, \mathrm{Rb}$ and $\mathrm{Si}$, exhibit similar variations, intensity values are high in fine-grained intervals while low values in coarse-grained intervals. The $\mathrm{Zr}$ is also related to intervals rich in fine particles. However, the maximum values are only detected at the bottom of the core. The highest values of $\mathrm{Sr}$ and $\mathrm{Ca}$ are also found in the bottom, but unlike the first group, both elements show peaks in sandy layers. 
Table 1. ${ }^{14} \mathrm{C}$ data for mollusk shells from MC45. ${ }^{14} \mathrm{C}$ ages are calibrated using the Marine13 calibration curve with reservoir age $\Delta R$ of -218 , model Ages were obtained by the "clam" R-code package.

\begin{tabular}{llrrll}
\hline Lab code & Shell used & $\begin{array}{r}\text { Depth } \\
(\mathrm{cm})\end{array}$ & $\begin{array}{r}\delta^{13} \mathrm{C} \\
\% 0\end{array}$ & $\begin{array}{l}{ }^{14} \mathrm{C} \text { ages } \\
(\mathrm{BP})\end{array}$ & $\begin{array}{l}\text { Clam model } \\
\text { ages (AD) }\end{array}$ \\
\hline SacA 28609 & Loripes lacteus & 22 & 4.8 & $235 \pm 30$ & $1854 \pm 93$ \\
SacA 26943 & Cerastoderma glaucum & 32 & 2.40 & $730 \pm 30$ & $1393 \pm 62^{*}$ \\
SacA 26944 & Cerastoderma glaucum & 46 & 0.70 & $575 \pm 30$ & $1537 \pm 76$ \\
SacA 26945 & Cerastoderma glaucum & 50 & 2.4 & $630 \pm 30$ & $1476 \pm 48$ \\
SacA 28610 & Cerastoderma glaucum & 56 & 3.8 & $645 \pm 30$ & $1464 \pm 45^{*}$ \\
SacA 28611 & Parvicardium exiguum & 64 & 4 & $620 \pm 30$ & $1483 \pm 47$ \\
SacA 26946 & Acanthocardia mucronata & 91 & 4.40 & $1340 \pm 30$ & $831 \pm 91^{*}$ \\
SacA 26947 & Cerastoderma glaucum & 104 & 6.50 & $1035 \pm 30$ & $1149 \pm 87$ \\
\hline
\end{tabular}

* inverse ages.
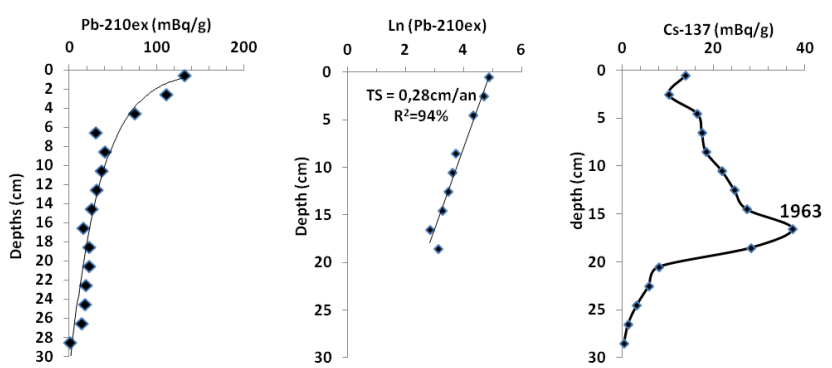

Figure 4. Profile distributions of ${ }^{210} \mathrm{~Pb}_{\mathrm{ex}}$ and ${ }^{137} \mathrm{Cs}$ activity concentration vs. depth in MC45 core. Using the CFCS (Constant Flux, Constant Sedimentation Rate) model, the ${ }^{210} \mathrm{~Pb}$ data indicate a sedimentation rate of $0.28 \mathrm{~cm}_{\text {year }}{ }^{-1}$. The activity depth profile ${ }^{137} \mathrm{Cs}$ displays a peak at $16 \mathrm{~cm}$, resulting in accumulation rates of $0.3 \mathrm{~cm}$ year $^{-1}$ for the 1963 depths.

\subsection{Age-depth model and sedimentation rate}

Measured ${ }^{210} \mathrm{~Pb}$ values in the uppermost $30 \mathrm{~cm}$ of the MC45 core range from 132.6 to $1.7 \mathrm{mBq} \mathrm{g}^{-1}$. In general, the downcore distribution of excess ${ }^{210} \mathrm{~Pb}$ values follows a relatively exponential decrease with depth. Therefore a constant flux, constant supply CF: CS sedimentation model was applied. The indicated sedimentation rate is about $0.28 \mathrm{~cm}_{\text {year }}{ }^{-1}$.

The profile distribution of ${ }^{137} \mathrm{Cs}$ activity (Fig. 4) shows the maximum depth at $16 \mathrm{~cm}$. This may represent the period of maximum radionuclide fallout in the Northern Hemisphere associated with the peak of atomic weapons testing in 1963. The ${ }^{137}$ Cs-derived sedimentation rate $\left(0.34 \mathrm{~cm}_{\text {year }}{ }^{-1}\right)$ is more important than the ${ }^{210} \mathrm{~Pb}$ rate.

Eight lagoonal shells (Cerastoderma Glaucum, Loripes lacteus ... etc.) sampled from the MC45 lagoon core were dated using conventional ${ }^{14} \mathrm{C}$-AMS measurements, and obtained dates were calibrated using the Marine13 curve (Reimer et al., 2013) (Table 1). The modern ${ }^{14} \mathrm{C}$ reservoir age in the Nador lagoon was estimated using the radiocarbon date within ${ }^{210} \mathrm{~Pb}_{\mathrm{ex}}$-time domain. Sea surface reservoir ${ }^{14} \mathrm{C}$ ages $R(t)$ for the modern shell (SacA 28609) were cal-

culated by subtracting the atmospheric ${ }^{14} \mathrm{C}$ value estimated for the historical date AD $1930\left(152 \pm 7{ }^{14} \mathrm{C}\right.$ years; Reimer et al., 2013) from the measured apparent ${ }^{14} \mathrm{C}$ ages of the mollusk $\left(235 \pm 30{ }^{14} \mathrm{C}\right.$ years, Table 2$)$. This gives an $R(t)$ value of 83 years. The deviance from the global mean reservoir age $(\Delta R)$ is then obtained by subtracting the marine model age value estimated for AD $1930\left(453 \pm 23{ }^{14} \mathrm{C}\right.$ years; Reimer et al., 2013) from the measured apparent ${ }^{14} \mathrm{C}$ age of the shell $\left(235 \pm 30{ }^{14} \mathrm{C}\right.$ years (Table 2). The $\Delta R$ of about -218 years is thus estimated and adopted (Table 2 ). The negative $\Delta R$ value is common in shallow oceanic regions or in enclosed lagoons, where (i) the ${ }^{14} \mathrm{C}$ in seawater DIC (dissolved inorganic carbon) are higher than the average global ocean, and (ii) ${ }^{14} \mathrm{C}$ mixing with depleted water from deeper ocean is limited (Dutta, 2008). However, this value should be taken with caution, due to (i) intra-shell variation in radiocarbon age, which can be significant ( $\sim 200$ years) (Jones et al., 2007), and (ii) to possible variations in relation to paleoenvironmental changes (Sabatier et al., 2010).

The age model of MC45 core was realized by fitting a linear regression using the "clam" R-code package version 2.2 (Blaauw, 2010) on ${ }^{14} \mathrm{C}$ ages (without inverse ages) and ${ }^{210} \mathrm{~Pb}_{\mathrm{ex}} /{ }^{137} \mathrm{Cs}$ (Fig. 5). The ${ }^{14} \mathrm{C}$ mean sedimentation rate calculated is $0.10 \mathrm{~cm}_{\text {year }}{ }^{-1}$. In this context, it should be noted that the presence of bioturbation could influence ${ }^{210} \mathrm{~Pb}$ or ${ }^{137} \mathrm{Cs}$ decay profiles, providing an over-estimate value of the accumulation rate and creating an inaccuracy in the radiocarbon reservoir correction and then in the final age model. In our case, any sediment reworking by organisms has been observed during the preparation of sediment core (e.g., tubebuilding polychaete), X-ray images also confirm the absence of physical mixing. Furthermore, the agreement between average sedimentation rates derived from ${ }^{210} \mathrm{~Pb},{ }^{137} \mathrm{Cs}$ and ${ }^{14} \mathrm{C}$ suggests that the various disturbing processes like bioturbation did not play a major role in the studied parts of the cores. 
Table 2. ${ }^{14} \mathrm{C}$ date of modern pre-bomb shell samples in MC45 core and its reservoir ages. Estimation of $R(t)$ and $\Delta R$ were estimated using the ${ }^{210} \mathrm{~Pb}_{\text {ex }}$ date.

\begin{tabular}{lcccccc}
\hline Lab code & $\begin{array}{c}{ }^{210} \mathrm{~Pb} \\
\text { age (AD) }\end{array}$ & $\begin{array}{c}{ }^{14} \mathrm{C} \\
\text { year (BP) }\end{array}$ & $\begin{array}{c}\text { Tree-ring }{ }^{14} \mathrm{C} \\
\text { age (BP) IntCal13 }\end{array}$ & $\begin{array}{c}\text { Reservoir age } \\
R(t) \text { (year) }\end{array}$ & $\begin{array}{c}\text { Model age } \\
\text { (Marine13 curve) }\end{array}$ & $\begin{array}{c}\Delta R \\
\text { (year) }\end{array}$ \\
\hline SacA 28609 & 1930 & $235 \pm 30$ & $152 \pm 7$ & 83 & $453 \pm 23$ & -218 \\
\hline
\end{tabular}

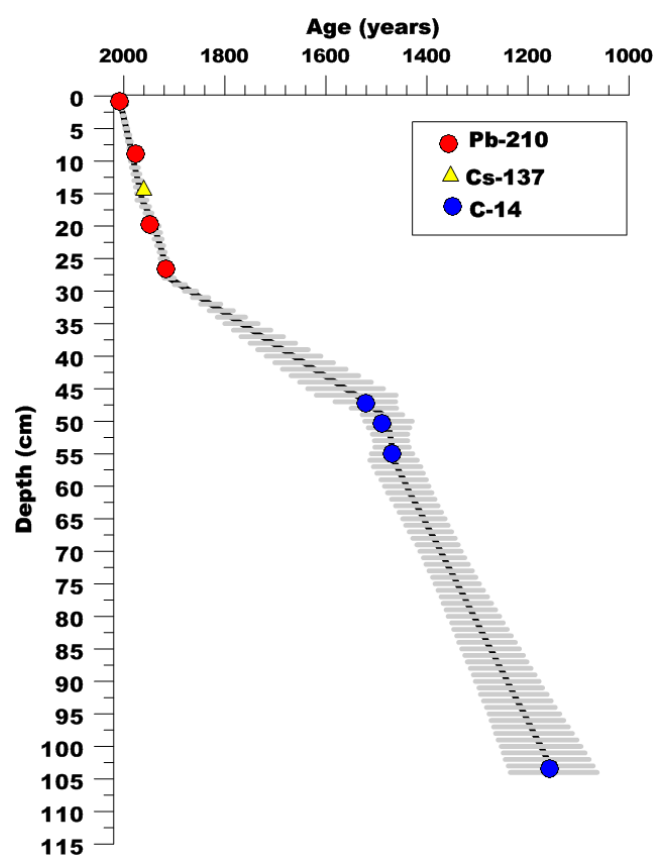

Figure 5. Stratigraphic age-depth plot of the MC45 core undertaken in the clam code package (Blaauw, 2010). Clam settings: linear interpolation; 1000 iterations weighted by calibrated probabilities at $95 \%$ confidence ranges and resolution 1 year steps. Clam output statistics: $0-104 \mathrm{~cm}$ with age reversals were removed.

\subsubsection{Sediments source}

The sedimentation in the Nador lagoon is mostly controlled by terrestrial and marine inputs. Rivers are the main source of fine sediments dispersed within the lagoon, while marine sediments consist mainly of coarse carbonate sand (Inani, 1995; Mahjoubi, 2001; Bloundi, 2005). In order to characterize the lagoon barrier beach sand samples, the spectrum of the grain size percentages vs. grain size was plotted; the results show unimodal distribution with one mean grain population ranging between 133 and $282 \mu \mathrm{m}$. The percentages of this grain size class in surface samples decrease considerably from the sea to the lagoon (Fig. 6); therefore, it can be used successfully to trace marine sand in lagoon sediments.

The geochemical data obtained by a XRF portable analyzer allowed the detection of 11 elements (Ti, Fe, Sr, Cu, Zn, $\mathrm{Zr}, \mathrm{Mn}, \mathrm{Co}, \mathrm{As}, \mathrm{Rb}$, and $\mathrm{Pb}$ ). Variation of the concentration of the most important detected elements from sea to continen-

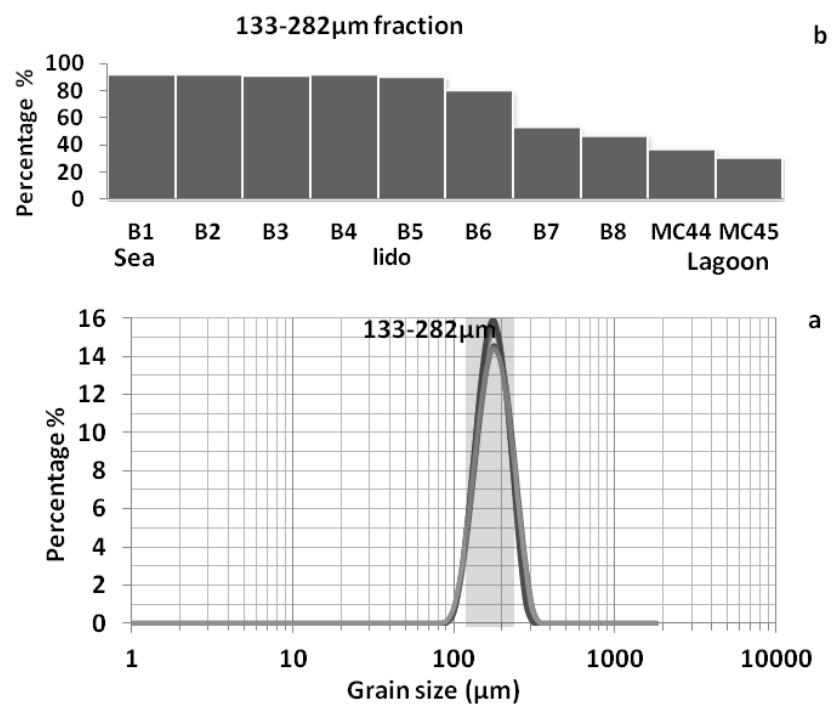

Figure 6. Grain size of lido sand in the Nador lagoon. (a) The spectrum of the grain size percentages vs. grain size with unimodal distribution (133 and $282 \mu \mathrm{m})$. (b) Distribution of 133-282 fraction along sea-lagoon transect.

tal samples (Fig. 7) shows that the elemental composition of barrier beach sediments are enriched in $\mathrm{Sr}$ and depleted in $\mathrm{Fe}, \mathrm{Ti}, \mathrm{Mn}$ and $\mathrm{Rb}$. Although these results are based on a limited number of samples and detected elements, they are in agreement with previous studies in the area (Mahjoubi, 2001; Bloundi, 2005). Indeed, in the Nador lagoon two groups can be identified: the first group is composed of $\mathrm{Al}, \mathrm{Fe}, \mathrm{K}, \mathrm{Mn}$, $\mathrm{S}$, $\mathrm{Ti}$ and $\mathrm{Mg}$, these elements are associated with clay and Feldspar and the maximum concentrations are found mainly on the continental part of the lagoon. The second group is composed of $\mathrm{Ca}$ and $\mathrm{Sr}$, where the calcium is mainly of marine origin and characterized as being biogenic and calcareous (Bloundi, 2005). Regarding Si, its terrestrial origin is mainly from feldspar and clay minerals while the marine $\mathrm{Si}$ comes mainly from quartz.

In order to trace marine sediment geochemically, interelement ratios of terrestrial elements and marine elements can be used. Additionally, the use of inter-element ratios presents the advantage to be insensitive to dilution and matrix effects (Richter et al., 2006; Croudace et al., 2006). 

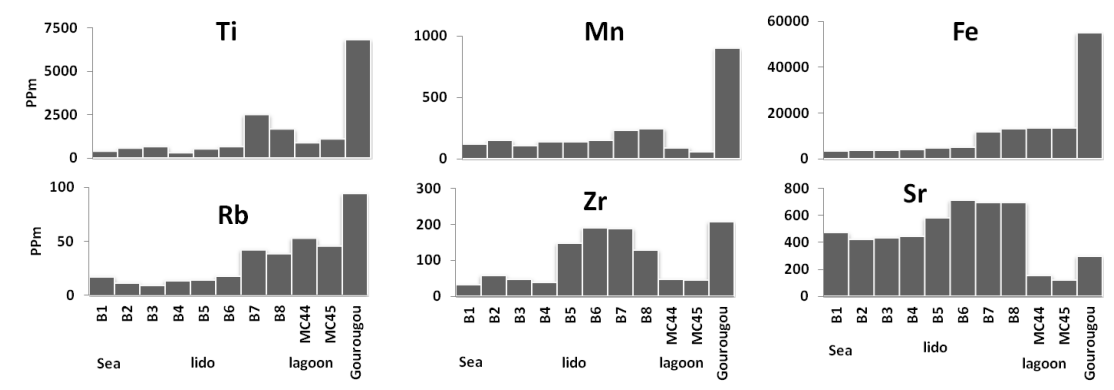

Figure 7. Distribution of geochemical elements concentration (ppm) along sea-lagoon-continental board transect.

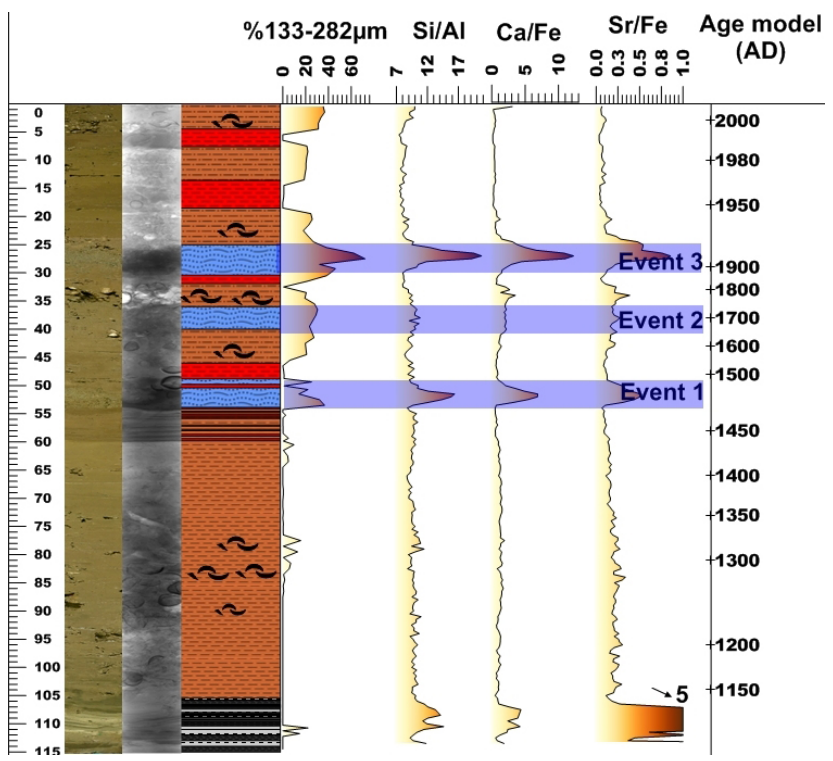

Figure 8. Identification of paleoevents based on photography, radiography $\mathrm{X}, \log$, grain size and geochemical inter-element ratios. The identified events show coarse grained texture in photography, dark layer in radiography $\mathrm{X}$, high percentage of $133-282 \mu \mathrm{m}$ fraction and peaks of $\mathrm{Si} / \mathrm{Al}, \mathrm{Ca} / \mathrm{Fe}$ and $\mathrm{Sr} / \mathrm{Fe}$ ratios.

\subsubsection{Identification of paleoevents}

The evolution with depth of the 133-282 $\mu \mathrm{m}$ grain size population in MC45 core shows five peaks; all are over the last 600 years. However, only three events are confirmed by geochemical data (Fig. 8). Indeed, the selected inter-element ratios $(\mathrm{Si} / \mathrm{Al}, \mathrm{Ca} / \mathrm{Fe}$ and $\mathrm{Sr} / \mathrm{Fe}$ ) show important peaks for the events 1,2 and 3 . An increase of inter-element-ratio value is also observed in the bottom core, this is not related to the presence of coarse sediments, but rather to the gypsum crystals (enriched en $\mathrm{Ca}$ and $\mathrm{Sr}$ and depleted en $\mathrm{Al}$ and $\mathrm{Fe}$ ).

Based on all of the above results, we can confidently assume that the events 1,2 , and 3 correspond to paleooverwash events. The age model indicates that overwash layer "1" was probably deposited between Cal AD 1438 to 1524, the overwash "2" between Cal AD 1610 to 1799 and overwash "3" between Cal AD 1856 to 1899.

\subsection{Storm or tsunami events?}

Generally, both tsunamis and storms cause brief coastal flooding with high overland flow velocities. Distinguishing tsunami and storm deposits is still controversial and several studies have pointed out many hypotheses regarding the diagnostic characteristics of storm/tsunami deposits (Kortekaas and Dawson, 2007; Morton et al., 2007; Tappin, 2007; Engel and Brückner, 2011).

Local and regional historic documents with tsunami catalogues are one of the best ways to correlate identified events with historical recorded tsunamis or storm events. During the last 600 years, the following four tsunamis were recorded in the western Mediterranean coast. (i) The first is the 22 September 1522 tsunami. The geographic position of the Nador lagoon is directly exposed to the 1522 tsunami event, and does not let us not exclude its impact on Nador area. (ii) The 9 October 1680 tsunami (Málaga) is not supported by the available information in contemporary documents (Goded et al., 2008). Besides, the Nador lagoon is not geographically exposed to the 1680 tsunami event. (iii) The 9 October 1790 tsunami which caused flooding of the northern shore of Africa and southern shore of Spain (Soloviev et al., 2000). No documentation supports tsunami waves on the Moroccan coast, but the extent of the tsunami event on Algerian coast and its manifestation on the southern coast of Spain leads to assume a possible impact on the northern Moroccan coast (Kaabouben et al., 2009). (iv) Finally, the 21 August 1856 of this tsunami on the northeastern shore of Algeria (Jijel, $300 \mathrm{~km}$ east of Algiers) (Soloviev et al., 2000); the effects of this event on the Moroccan coasts is improbable (Kaabouben et al., 2009).

In the Nador area, the well-recorded sea storms are those who opened inlets along the lagoon lido. The oldest one is the 1889 strong storm caused by north-to-northeast winds and which occasioned a large inlet of $150 \mathrm{~m}$ width. The paleoinlets 3 and 5 (Fig. 1) were, respectively, the results of recent storms of 1941 and 1981. The inlet 1 was opened artificially in 1909, but was enlarged by storm effects. In addition, it should be noted that in the western Mediterranean, storms had a higher frequency in the Little Ice Age (LIA), with two lesser periods of high frequency in the 1400s and 
at the end of the 1700s (Camuffo et al., 2000). Other studies confirmed increased intensity and frequency of storms during the LIA in the Mediterranean, as for example in the French coast (Dezileau et al., 2011). Based on a set of six simulations of the LIA using an ocean-atmosphere general circulation model (OAGCM), Raible et al. (2006) consistently found an increase in cyclone occurrence in the Mediterranean during the LIA compared to present-day.

Considering all these historical data, we can confidently assume that event event 3 corresponds to 1889 storms because of its date located in the event- 3 age interval and also because of the paleo-overwash located in front of the coring site generated by this event. For the events 1 and 2, the tsunami-storm hypothesis remains open. Indeed, even if they are probably related to sea storms because of the increase of these phenomena during this period in the western Mediterranean, both the tsunamis of both 1522 and 1790 seem to have also affected the Nador area during event interval ages 1 and 2, respectively. Based on examples of modern tsunami and storm deposits, some sedimentological criteria can be used to identify tsunami from storm deposit (Morton et al., 2007). The tsunami deposit has a relatively thin bed consisting of a single structureless bed or a bed with only a few thin layers. The presence of internal mud laminae or intraclasts indicates tsunami deposits. The storm origin deposit presents a moderately thick sand bed composed of numerous subhorizontal planar laminations organized into multiple laminasets. The stratification associated with bed-load transport and abundant shell fragments organized in laminations also favor a storm origin. In our case, all of the events deposits identified are observed as a single homogeneous bed ( $\sim 2-5 \mathrm{~cm}$ thick). Within it, no sedimentary structures (ripple crossbeds, planar laminae or mud intraclasts) were observed; only event 3 contains internal mud laminae within the deposit. However, even if these criteria favor tsunami origin, this observation should be taken with caution because the use of a single sediment core results make it inadequate for physical distinction process (Morton et al., 2007). About the use of geochemical signatures to distinguish between tsunami and storm deposits, no study was found. The increase in geochemical elements indicating marine origin as evidence of marine inundation is generally used in both deposits (Engel et al., 2010; Ramírez-Herrera et al., 2012).

\section{Conclusions}

The present study is a first attempt for the reconstitution of paleo-events in the Nador lagoon; the use of a multiproxy analysis by lithological evidence and X-ray fluorescence has revealed distinct anomalies and allowed differentiation of stratigraphic intervals which are interpreted as event horizons. Eight radiocarbon dates of shells samples combined with ${ }^{210} \mathrm{~Pb}$ and ${ }^{137} \mathrm{Cs}$ chronologies allowed to estab- lish a chronological framework, which was used to calculate a time-averaged sedimentation rate $\left(0.10\right.$ to $\left.0.28 \mathrm{~cm}_{\text {year }}{ }^{-1}\right)$.

Three events were identified; all of them are concentrated over the last 500 years. Attribute these deposits to tsunami or storm events was not an easy task; historically only the modern event can be attributed with certainty to a 1889 major storm. The sedimentological and geochemical data were not very helpful in this process because of the single core studied but they could probably be more indicative by correlation with other cores in the area.

Acknowledgements. The authors would like to thank all participants in the coring expedition, particularly O. Ther (Technician, U. Bordeaux), E. Regnier (Technician, LSCE - IPSL, Paris) and P. Blanchemanche (Pr. Archeo-Montpellier) for their collaboration in the various stages of this study. The authors wish to thank also the staff of MarChica Med Company (Rabat and Nador) for their assistance during the entire period of the expedition. This study is funded by the MISTRALS/PALEOMEX project (Coord. Sicre, M. A., Guyot, J., Dezileau, L.,) and PHC-Volubilis (MA/11/253; coord.: L. Dezileau and M. Snoussi).

Edited by: N. Pinardi

Reviewed by: O. Das and one anonymous referee

\section{References}

Blaauw, M.: Methods and code for "classical" age-modelling of radiocarbon sequences, Quat. Geochronol., 5, 512-518, 2010.

Bloundi, M. K.: Etude géochimique de la lagune de Nador (Maroc oriental): Impacts des facteurs anthropiques, $\mathrm{PhD}$ thesis: Univ. Louis Pasteur, France \& Univ. Mohammed V-Agdal, Maroc, 238 pp., 2005.

Campins, J., Jansà, A., and Genovés, A.: Three-dimensional structure of western Mediterranean cyclones, Int. J. Climatol., 26, 323-343, 2006.

Camuffo, D., Secco, C., Brimblecombe, P., and Martin-Vide, J.: Sea storms in the Adriatic Sea and the Western Mediterranean during the last millennium, Climatic Change, 46, 209-223, 2000.

Collins, E. S., Scott, D. B., and Gayes, P. T.: Hurricane records on the South Carolina coast: can they be detected in the sediment record?, Quaternary Int., 56, 15-26, 1999.

Croudace, I. W., Rindby, A., and Rothwell, R. G.: ITRAX: description and evaluation of a new multi-function X-ray core scanner, Special publication-geological society of London, 267, 51-63, 2006.

Das, O., Wang, Y., Donoghue, J., Xu, X., Coor, J., Elsner, J., and $\mathrm{Xu}, \mathrm{Y}$.: Reconstruction of paleostorm and paleoenvironment history using geochemical proxies archived in the sediments of two coastal lakes in NW Florida. Quaternary Sci. Rev., 68, 142-153, 2013.

Dezileau, L., Bordelais, S., Condomines, M., Bouchette, F., and Briqueu, L.: Evolution des lagunes du Golfe d'Aigues-Mortes à partir de l'étude de carottes sédimentaires courtes (étude géochronologique, sédimentologique et géochimique des sédiments récents), Publications ASF, Paris, Vol. 51, p. 91, 2005. 
Dezileau, L., Sabatier, P., Blanchemanche, P., Joly, B., Swingedouw, D., Cassou, C., Castaings, J., Martinez, P., and Von Grafenstein, U.: Intense storm activity during the Little Ice Age on the French Mediterranean coast, Palaeogeogr. Palaeocl., 299, 289-297, 2011.

Donnelly, J. P. and Woodruff, J. D.: Intense hurricane activity over the past 5,000 years controlled by El Nino and the West African monsoon, Nature, 447, 465-468, 2007.

Dutta, K.: Marine ${ }^{14} \mathrm{C}$ Reservoir Age and Suess Effect in the Indian Ocean, Earth Sci. India, 1, 243-257, 2008.

Engel, M. and Brückner, H.: The identification of palaeo-tsunami deposits - a major challenge in coastal sedimentary research, Dynamische Küsten-Grundlagen, Zusammenhänge und Auswirkungen im Spiegel angewandter Küstenforschung, Proceedings of the 28th Annual Meeting of the German Working Group on Geography of Oceans and Coasts, 22-25, 2011.

Engel, M., Brückner, H., Wennrich, V., Scheffers, A., Kelletat, D., Vött, A., Schäbitz, F., Daut, G., Willershäuser, T., and May, S. M.: Coastal stratigraphies of eastern Bonaire (Netherlands Antilles): New insights into the palaeo-tsunami history of the southern Caribbean, Sediment. Geol., 231, 14-30, 2010.

Goded, T., Buforn, E., and Muñoz, D.: The 1494 and 1680 Málaga (southern Spain) earthquakes, Seismol. Res. Lett., 79, 707-715, 2008.

Goldberg, E.: Geochronology with lead-210, International Atomic Energy Agency, 121-131, 1963.

Gonzalez, M., Medina, R., Olabarrieta, M., and Otero, L.: Tsunami Hazard Assessment on the Southern Coast of Spain, Turkish J. Earth Sci., 19, 351-366, 2010.

Hamoumi, N.: The Nador barrier island system (Morocco): functioning, natural and man-induced controls, scenarios of future evolutions, Revue Paralia, 5, 5.15-5.28, 2012.

Inani, I.: Dynamique sédimentaire et état de la pollution dans la lagune de Nador, Thèse de Doctorat, Univ. Mohamed V, Fac.Sci. Rabat, 186 pp., 1995.

Irzi, Z.: Les Environnements du Littoral méditerranéen du Maroc compris entre l'oued Kiss et le Cap des trois Fourches dynamique sédimentaire et évolution et écologie des foraminifères benthiques de la lagune de Nador, Doctorat d'Etat ès Sciences. Univ Mohammed I, Oujda, 279 pp., 2002.

Jones, K. B., Hodgins, G. L., Dettman, D. L., Andrus, C., Nelson, A., and Etayo-Cadavid, M. F.: Seasonal variations in Peruvian marine reservoir age from pre-bomb Argopecten purpuratus shell carbonate, Radiocarbon, 49, 877-888, 2007.

Kaabouben, F., Baptista, M. A., Iben Brahim, A., El Mouraouah, A., and Toto, A.: On the moroccan tsunami catalogue, Nat. Hazards Earth Syst. Sci., 9, 1227-1236, doi:10.5194/nhess-9-1227-2009, 2009.

Kortekaas, S. and Dawson, A.: Distinguishing tsunami and storm deposits: an example from Martinhal, SW Portugal, Sediment. Geol., 200, 208-221, 2007.

Krishnaswamy, S., Lal, D., Martin, J., and Meybeck, M.: Geochronology of lake sediments, Earth Planet. Sci. Lett., 11, 407-414, 1971.

Lionello, P., Bhend, J., Buzzi, A., Della-Marta, P., Krichak, S., Jansa, A., Maheras, P., Sanna, A., Trigo, I., and Trigo, R.: Cyclones in the Mediterranean region: climatology and effects on the environment, Developments in Earth and Environmental Sciences, 4, 325-372, 2006.
Liu, K.-B. and Fearn, M. L.: Lake-sediment record of late Holocene hurricane activities from coastal Alabama, Geology, 21, 793796, 1993.

Mahjoubi, R.: Nature et origine du flux de matières particulaires et son enregistrement dans un milieu paralique microtidal: cas de la lagune de Nador (Maroc nord oriental), Doctorat d'Etat ès Sciences, Univ Moulay Ismail, Meknès, 273 pp., 2001.

Morel, J. L.: Les événements tectoniques et volcaniques responsables de la regression messinienne dans le Maroc septentrional: Exemple du bassin d'Iaddouyine (Segangane-Rif OrientalMaroc), Bulletin de l'Institut Scientifique, Rabat, 97-106, 1985.

Morton, R. A., Gelfenbaum, G., and Jaffe, B. E.: Physical criteria for distinguishing sandy tsunami and storm deposits using modern examples, Sediment. Geol., 200, 184-207, 2007.

Nott, J.: The tsunami hypothesis - comparisons of the field evidence against the effects, on the Western Australian coast, of some of the most powerful storms on Earth, Marine Geol., 208, 1-12, 2004.

Papadopoulos, G. A. and Fokaefs, A.: Strong tsunamis in the Mediterranean Sea: a re-evaluation, ISET J. Earthquake Technol., 42, 159-170, 2005.

Raible, C. C., Casty, C., Luterbacher, J., Pauling, A., Esper, J., Frank, D. C., and Wanner, H.: Climate variabilityobservations, reconstructions, and model simulations for the Atlantic-European and Alpine region from 1500-2100 AD, Climatic Change, 79, 9-29, 2006.

Ramírez-Herrera, M.-T., Lagos, M., Hutchinson, I., Kostoglodov, V., Machain, M. L., Caballero, M., Goguitchaichvili, A., Aguilar, B., Chagué-Goff, C., and Goff, J.: Extreme wave deposits on the Pacific coast of Mexico: Tsunamis or storms? - A multi-proxy approach, Geomorphology, 139, 360-371, 2012.

Reicherter, K. and Becker-Heidmann, P.: Tsunami deposits in the western Mediterranean: remains of the 1522 Almería earthquake?, Geol. Soc. Spec. Publ., 316, 217-235, 2009.

Reimer, P. J., Bard, E., Bayliss, A., Beck, J. W., Blackwell, P. G., Ramsey, C. B., Grootes, P. M., Guilderson, T. P., Haflidason, H., and Hajdas, I.: IntCal13 and Marine13 radiocarbon age calibration curves 0-50,000 years cal BP, Radiocarbon, 55, 1869-1887, 2013.

RGPH: Recensement General de la Population et de l'Habitat. Caractéristiques démographiques et socio économiques de la population. Rapport national, 166 pp., 2004.

Richter, T. O., Van der Gaast, S., Koster, B., Vaars, A., Gieles, R., de Stigter, H. C., and van Weering, T. C.: The Avaatech XRF Core Scanner: technical description and applications to NE Atlantic sediments, Geol. Soc. Spec. Publ., 267, 39-50, 2006.

Robbins, J. A. and Edgington, D. N.: Determination of recent sedimentation rates in Lake Michigan using Pb-210 and Cs-137, Geochim. Cosmochim. Ac., 39, 285-304, 1975.

Sabatier, P., Dezileau, L., Condomines, M., Briqueu, L., Colin, C., Bouchette, F., Le Duff, M., and Blanchemanche, P.: Reconstruction of paleostorm events in a coastal lagoon (Herault, South of France), Marine Geol., 251, 224-232, 2008

Sabatier, P., Dezileau, L., Blanchemanche, P., Siani, G., Condomines, M., and Bentaleb, I.: Holocene variations of radiocarbon reservoir ages in a Mediterranean lagoonal system, Radiocarbon, 52, 91-102, 2010.

Sabatier, P., Dezileau, L., Colin, C., Briqueu, L., Bouchette, F., Martinez, P., and Von Grafenstein, U.: 7000 years of paleostorm ac- 
tivity in the NW Mediterranean Sea in response to Holocene climate events, Quaternary Res., 77, 1-11, 2012.

Scileppi, E. and Donnelly, J. P.: Sedimentary evidence of hurricane strikes in western Long Island, NY, Geochem. Geophy. Geosys., 8, Q06011, doi:10.1029/2006GC001463, 2007.

Soloviev, S. L., Solovieva, O. N., Go, C. N., Kim, K. S., and Shchetnikov, N. A.: Tsunamis in the Mediterranean Sea 2000 BC-2000 AD, Vol. 237, edited by: Bonnin, J., Levin, B. W., Tinti, S., and Papadopoulos, G. A., Dordrecht: Kluwer Academic Publishers, 2000.

Tappin, D. R.: Sedimentary features of tsunami deposits - Their origin, recognition and discrimination: An introduction, Sediment. Geol., 200, 151-154, 2007.
Tisnérat-Laborde, N., Poupeau, J., Tannau, J., and Paterne, M.: Development of a semi-automated system for routine preparation of carbonate samples, Radiocarbon, 43, 299-304, 2006.

Woodruff, J. D., Donnelly, J. P., Mohrig, D., and Geyer, W. R.: Reconstructing relative flooding intensities responsible for hurricane-induced deposits from Laguna Playa Grande, Vieques, Puerto Rico, Geology, 36, 391-394, 2008.

Yu, K.-F., Zhao, J.-X., Shi, Q., and Meng, Q.-S.: Reconstruction of storm/tsunami records over the last 4000 years using transported coral blocks and lagoon sediments in the southern South China Sea, Quaternary Int., 195, 128-137, 2009. 